\title{
Gender Analysis of Marriage Guardians in the Compilation of Islamic Law
}

\author{
Abd. Rasyid Sidiq ${ }^{*}$, Rusli Rusli ${ }^{2}$, Syahabuddin Syahabuddin ${ }^{3}$ \\ 1 Islamic Family Law Department, Postgraduate, Institut Agama Islam Negeri Palu \\ 2 Islamic Family Law Department, Postgraduate, Institut Agama Islam Negeri Palu \\ ${ }^{3}$ Islamic Family Law Department, Postgraduate, Institut Agama Islam Negeri Palu
}

\begin{abstract}
The concept of marriage guardians in Islamic Law Compilation still seems biased and patriarchal, because women do not have the right to marry themselves or others. Articles on guardian of marriage are still less responsive to women's interests. A gender imbalance regarding the concept of marriage guardians is further strengthened by the provisions of marriage guardians in the Islamic Law Compilation which are strictly aimed at men. This research used literature review method based on the Compilation of Islamic Law and gender theory. This study found that, the information about guardian of marriage which is a man's right from the father's line is actually in line with the pagan Arab culture, including the contribution of Quraish hegemony in interpreting religious propositions. In this regard, Arab societies like Quraish had great respect for a person based on their lineage, so that everyone who was respected would wholeheartedly keep their honor. The lineage in Arabic culture is in the hands of the male lineage, and women are entered into second-class citizens in front of them.
\end{abstract}

ARTICLE

INFORMATION

\section{Introduction}

e-ISSN: 2715-4580

p-ISSN: 2715-8268 
In principle, marriage in Islam carries the norms that support the creation of an atmosphere of peace, prosperity, justice and equality in the family. However, due to the disproportionate influence of interpretations, it frequently raises some formulations of Islamic teachings related to marriage that not defend the interests of women. ${ }^{1}$

In Islam, marriage is a contract between a man and a woman on an equal position. A woman as an equal party to a man can set the desired conditions, as a man. ${ }^{2}$ Marriage is a sacred agreement between a man and a woman to fulfill the purpose of married life as husband and wife by fulfilling the requirements and pillars that have been determined by Islamic law. ${ }^{3}$ Marriage aims to realize a sakinah, mawaddah, and rahmah household life. ${ }^{4}$ Meanwhile, other goals are the achievement of reproductive goals, fulfillment of biological needs, and as a form of protecting oneself from

1 See Rusli Rusli, "An Analysis of Islamic Feminism in Indonesia: Reconstruction of Islamic Legal Issues on Gender Relations," Hunafa: Jurnal Studia Islamika 3, no. 1 (2006): 1-12, https://www.jurnalhunafa.org/index.php/huna fa/article/view/239.; See also Rusli Rusli, Islamic Feminism: Responses of Muslim Feminists to Gender Inequality in Indonesia (Palu: Irshed Press, 2006).

${ }^{2}$ Ashghar Ali Engineer, Hak-Hak Perempaun Dalam Islam, Terjemahan Farid Wajidi (Bandung: LSPPA, 1994), 138.

${ }^{3}$ Adnan Hafidh dan Ma'ruf Asroni, Tradisi Islami: Panduan Prosesi Kelahiran, Perkawinan Dan Kematian (Surabaya: Khalista, 2009), 88.

${ }^{4}$ Abdurrahman, Kompilasi Hukum Islam Indonesia (Jakarta: Akademika Pressindo, 2005), 114. immorality, as well as to perfect worship. ${ }^{5}$

One of the important marriage issues in Islam is the guardian of marriage, which is the pillar of marriage. In the Compilation of Islamic Law, the articles on marriage guardians, from a sociological point of view, are still less responsive to women's interests. A gender inequality regarding the concept of marriage guardian is further strengthened by the provisions of marriage guardian in the Compilation of Islamic Law which are expressly only addressed to men. ${ }^{6}$

The concept of guardian of marriage in the Compilation of Islamic Law still does not provide equal opportunities for all humans without discrimination on the basis of gender. The concept of guardian of marriage in the Compilation of Islamic Law is a crucial problem that needs to be analyzed from a gender perspective, because it does not reflect the principles of justice and gender equality, and. still smells of patriarchal culture. This encourages the author to study it further, about the concept of marriage guardian in the Compilation of Islamic Law in terms of gender perspective.

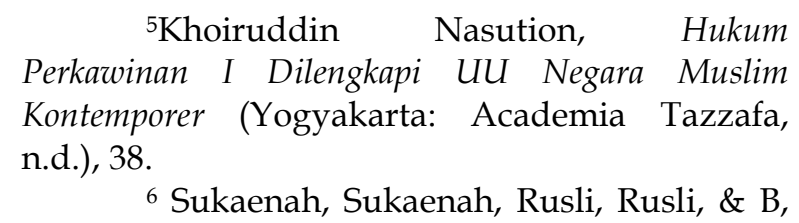
M. Taufan. (2020). The Effectiveness of Indonesia Supreme Court Regulation Number 1 Year 2016 Concerning Mediation of Marriage Disputes International Journal Of Contemporary Islamic Law And Society, 2(1), 63-80.

e-ISSN: $2715-4580$ p-ISSN: 2715-8268 


\section{Literature Review}

\section{A. The position of guardian in marriage}

In Indonesia, provisions relating to marriage are regulated in Marriage Law No. 1 of 1974 and Government Regulation no. 9 of 1975. In addition to these laws and regulations, there is also regulation, which is effectively used as guidelines by judges in the Religious Courts in the settlement of marriage cases, namely the Compilation of Islamic Law, through the Presidential Instruction of the Republic of Indonesia No. 1 of 1991 concerning the Compilation of Islamic Law. ${ }^{7}$

The Islamic Law Compilation was compiled to complement the Marriage Law. As a practical implementation of the Marriage Law, the material must not conflict with the Marriage Law. ${ }^{8}$

Marriage in Islam is very important. This can be seen in the myriad of legal verses related to marriage, divorce, ${ }^{9}$ and inheritance. In addition, hadiths were found to explain these

${ }^{7}$ Sukaenah, S., Rusli, R., \& B, M. T. (2020). The Effectiveness of Indonesia Supreme Court Regulation Number 1 Year 2016 Concerning Mediation of Marriage Disputes INTERNATIONAL JOURNAL OF CONTEMPORARY ISLAMIC LAW AND SOCIETY, 2(1), 63-80.

8 Yunus, H., Rusli, R., \& Abidin, A. (2020). The Concept of A Marriage Agreement in the Compilation of Islamic Law INTERNATIONAL JOURNAL OF CONTEMPORARY ISLAMIC LAW AND SOCIETY, 2(2), 35-45.

9 Forthe study of divorce from Quranic perspective see Rusli Rusli, "Hermeneutical Reading of Țalāq," HUNAFA: Jurnal Studia Islamika 12, no. 2 (2016): 209-229. issues. ${ }^{10}$ Among the marriage issues that have attracted the attention of Muslim jurists from a classical period to these days are marriage guardians.

A guardian is a person who is authorized to take legal action for the person he represents for the benefit of and on behalf of the person represented. Meanwhile, a guardian in marriage is a person who has the right to marry a woman he takes care of, if he is able to act as a guardian. If, for one reason, he is unable to act as a guardian, his guardianship rights pass to another person.

Because of the importance of guardian in marriage, so that it becomes the determinant of the validity of a marriage in Islam. Marriage can be declared valid, if the conditions and pillars of marriage have been fulfilled, both in positive law and Islamic law. Of the pillars of marriage that have been determined in Islam, the guardian of marriage is one of the most important things. In fact, according to Imam Syafi'i, marriage without a guardian is not valid for the bride, while for the prospective groom, a marriage guardian is not required for the marriage to be valid.

However, on a micro basis, there were no events that gave birth to this hadith of guardianship in marriage. However, to obtain an overview of the situation and conditions at the time this hadith was spoken several centuries ago,

10 Yunus, Haerunnisa, Rusli, Rusli, \& Abidin, Abidin. (2020). The Concept of A Marriage Agreement in the Compilation of Islamic Law International Journal Of Contemporary Islamic Law And Society, 2(2), 35-45.

e-ISSN: 2715-4580 p-ISSN: 2715-8268 
macro aspects can be used as a comparison to understand the hadith, of course in this case the social setting of pre-Islamic Arab society. Examining legal issues through a critical study of historical settings is reasonable, considering that Islamic law, as Joseph Schacht said, has its roots in pre-Islamic Arab society. ${ }^{11}$

To understand the tradition of guardianship in marriage, it is necessary to study the social setting of society at that time. The social system that developed in pre-Islamic Arab society was a patriarchy, which was considered as very unfavorable to women, because it contributed to the perpetuation of male domination over women. This patriarchal culture stems from the dominance of certain groups over other groups, not only limited to physical control, but also has an impact on determining the ideology that perpetuates its power. ${ }^{12}$

In the context of male-female relations, patriarchy has placed men as responsible for defending all family members and meeting their needs. Meanwhile, women are given the tasks related to reproduction. The form of male domination over women in pre-Islamic society got support from the geographical conditions of the Arabian

${ }^{11}$ Akhmad Minhaji, Kontroversi Pembentukan Hukum Islam (Yogyakarta: UII Press, 2001), 17.

12 Siti Ruhaini Dzuhayatin, "Pergulatan Pemikiran Feminis Dalam Wacana Islam Di Indonesia", in Siti Ruhaini Dzuhayatin, at.al., Rekonstruksi Metodologis Wacana Kesetaraan Gender dalam Islam (Yogyakarta: PSW UIN Sunan Kalijaga, 2002), 10.
Peninsula, which, in general, was desert surrounded by mountains so that it drives the struggle for water sources and livestock land.

In this society, women's lives are still very far from expectations as humans who have dignity because they only become the absolute property of a father and husband when they are married. According to Qasim Amin, in pre-Islamic society, women were like an item that could be traded and inherited. When a man had bought a woman from his father to serve as a wife, the ownership had indirectly been transferred to a husband, and he had the right either to resell or to make her a wife, and when the husband dies, the woman can be inherited by her heirs. ${ }^{13}$

The position of the guardian is very important. If a woman does not have a guardian at all, the Muslima jurists agree on the use of a magistrate guardian. If the guardian refuses to marry his daughter for reasons that are not in accordance with the provisions of Islamic law, such as the prospective husband of the married woman is poor, or is not handsome, or is uneducated, or comes from a different ethnic group, then her guardianship rights can be transferred to the guardian judge. The act of a guardian who does not want to marry a woman without any legal reason is prohibited and is considered an act of injustice to women. This is in accordance with the hadith of the Prophet Muhammad,

${ }^{13}$ Qasim Amin, Sejarah Penindasan Perempuan, Trans. Syariful Alam (Yogyakarta: IRCiSod, 2003), 29. 
“...if the guardian does not want to marry off his daughter, then the ruler is the guardian for women who do not have a guardian." (Narrated by al-Arba'ah)

The case is different, if the guardian does not want to marry for reasons justified by the Shari'a, such as the prospective husband of a different religion, or disabled or fasiq, such as gambler, drunkard, and adulterer.

Muslim scholars have different opinions on the issue of guardians. Imam Malik and Imam Syafi'i are of the opinion that there is no marriage without a guardian, and guardianship is a pillar for a valid marriage, while Imam Abu Hanifah states that if a woman performs a marriage contract without a guardian, while her husband-to-be is equal, the marriage may be allowed.

\section{B. Legal Basis of Marriage Guardian}

Guardian is one of the pillars of marriage which is a benchmark for the validity of a marriage. As stated in Article 19 of the Compilation of Islamic Law, "the guardian of marriage in marriage is a pillar that must be fulfilled for the prospective bride who acts to marry him off". ${ }^{14}$

In the Qur'an, there are also several verses that clearly inform that marriage is the business of the guardian, and the guardian is obliged to marry off his daughters who have never been married. In addition, there is also a provision that instructs the guardians so

14 Pustaka Widyatama, Kompilasi Hukum Islam, 1st ed. (Yogyakarta, 2004), 24. that they do not marry Muslim women with infidel men.

Some of these provisions are clearly addressed to the guardian, who emphasizes his very important position in marriage. If a woman has the right to directly marry herself to a man without a guardian, then for what purpose the the verse is addressed to the guardian, just as women marry women or also marry themselves, then the law is haram or prohibited. ${ }^{15}$

\section{Methodology}

This study used qualitative approach, $^{16}$ investigating marriage guardians in the Compilation of Islamic Law from a gender analysis. The researcher also used content analysis of the document obtained during the study was conducted.

Data were collected through intensive literature review of various books, journals, and Islamic literature. Data analysis consists of several procedures: reduction and verification techniques with various data sources. ${ }^{17}$

15 Mohd. Idris Ramulyo, Hukum Perkawinan, Hukum Kawansan, Hukum Acara Peradilan Agama Dan Zakat Menurut Hukum Islam, 1st ed. (Jakarta: Sinar Grafika, 1995), 5.

16 Nurdin, N., \& Yusuf, K. (2020). Knowledge management lifecycle in Islamic bank: the case of syariah banks in Indonesia. International Journal of Knowledge Management Studies, 11(1), 59-80. https://doi.org/10.1504/ijkms.2020.105073

17 Muslih, Imam, Nurdin, Nurdin, \& Marzuki, Marzuki. (2020). Effectiveness of Marriage Services Through Information System Management (SIMKAH) at Palu City Religious Court International Journal of Contemporary Islamic Law And Society, 2(1), 20-35.

e-ISSN: 2715-4580 p-ISSN: 2715-8268 
The reduced data is then analyzed reflecting on theoretical concepts used in this study.18

\section{Results and Discussion}

\subsection{The Concept of Guardian of Marriage in the Compilation of Islamic Law from a Gender Perspective}

Today, religion is often accused of being the source of gender inequality. Gender is a sex that is constructed by culture and customs, such as men being strong, brave, and intelligent, while women are weak, cowardly, and less intelligent. Gender issues are strengthened when differences between men and women give birth to injustice in various forms such as marginalization, subordination, or a negative image for women.

Meanwhile, the role of women is increasingly needed in various lines of life. As a logical consequence of marriage, several rights and obligations must be fulfilled by each partner. Thus, each partner has the same in the fulfillment of rights and the implementation of obligations. Equality in marriage has actually started in the pre-marital period, which Islam calls sekufu. The stipulation of sekufu (equality) as one of the conditions for marriage indicates that an important capital to realize the purpose of marriage, and this is dependent on equality. In the following discussion, a critical study of

18 Iqbal, M., Rusli, R., \& Musyahidah, M. (2019). Management Strategies of Professional Zakat Funds for Mustahiq Family Welfare By Amil Zakat Body International Journal of Contemporary Islamic Law And Society, 1(1), 39-51. the equality of rights and obligations between husband and wife will be described.

Scholars differ as to whether the position of a guardian is a condition for the validity of a marriage. The first opinion, which is based on a narration from Aisyah, says that "there is no marriage without a guardian" and a guardian is a condition for the validity of a marriage. Imam Syafi'i is among the first to hold this, and this is the opinion of the majority of Muslims in Indonesia. Even formally, the position of guardian, within the judiciary in Indonesia, "is a pillar that must be fulfilled to marry off the prospective bride." The second opinion, supported by Abu Hanifah, Zufar, al-Syaibi and al-Zuhri, argues that marriage without a guardian is valid, if the prospective husband is equal (sekufu). ${ }^{19}$

A guardian has the right of ijbar. This right is not absolute, it cannot be contested. This disproportionate interpretation of the right of $i j b a \hat{r}$ is one of the doors that opens opportunities for parents or guardians to act arbitrarily against girls who are about to marry. The reason commonly put forward by parents for exercising these rights is to provide the best for their daughters.

As stated by Imam Syafi'i, the right of ijbar for the guardian (parents) is intended to give the guardian the opportunity to do the best for the future

19 Ibn Rusyd, Bidayatul Mujtahid, Jilid II, Terjemahan Imam Ghazali Said \& Ahmad Zaidun (Jakarta: Pustaka Amani, 2007), 409.

e-ISSN: $2715-4580$ p-ISSN: $2715-8268$ 
of his daughter, by choosing his mate. ${ }^{20}$ At the time of the Prophet, as narrated by A'isha, a girl came to complain to her about her father forcing her to marry a man she did not like. After conveying it to the Messenger of Allah, the Prophet decided to return the marriage affairs to the girl. ${ }^{21}$

Ibn Taimiyah also agrees with the ulama who do not allow a father to force his daughter to marry without the her consent. $^{22}$ The same opinion was also expressed by Asghar Ali Engineer who said that in the Qur'an, women are equal to men in mental and moral abilities, so that each has the same independent right in determining his partner.

\subsection{Reconstruction of Gender Thought and Marriage Guardians in the Compilation of Islamic Law}

In the Quran, there is no single verse that shows the virtue of a person because of gender or descent. The independence and autonomy of women in the Islamic tradition from the beginning seemed so strong. Agreements, oaths, and vows made by women bind themselves as well as men. In Islamic tradition, adult women can make various agreements, oaths, and vows, both to fellow humans and God.

20 Muhammad al-Syarbini, Al-Iqna' (Surabaya: Dar al-Ihya' al-Kutub al-Arabiyyah, 2003), 168.

${ }^{21}$ Masdar Farid Mas'udi, Islam Dan HakHak Reproduksi Perempuan: Dilaog Fiqih Pemberdayaan (Bandung: Mizan, 1997), 90.

22 Ibnu Taimiyah, Hukum-Hukum Perkawinan, Alih Bahasa Oleh Rusnan Yahya (Jakarta: Pustaka al-Kausar, 1997), 124.
There is no power that can invalidate their promises, oaths, or vows.

This implies the ideal concept of gender equality and emphasizes that individual achievements, both in the spiritual field and in professional career, do not have to be monopolized by one gender alone. Men and women have the opportunity to get the same opportunity. However, in reality, this ideal concept requires socialization, because there are still a number of obstacles, especially cultural constraints.

The Qur'an highlights women as individuals. In this case, there is a difference between woman in their position as individual and woman as member of society. The Quran treats women and men equally. The statements of the Quran regarding the position of women can be seen in the following verses:

a. Women are God's creation, who has the same obligation to worship Him (al-Dhariyat: 56).

b. Women are partners for men (alNaba': 8)

c. Women together with men will also be individually responsible for their actions and choices (Maryam: 93-95).

d. Similar to the believing men, the believing women who do good deeds are promised by Allah happiness during their life on earth and eternal life in heaven (Al-Nahl: 97). ${ }^{23}$

In the Qur'an, it is not explicitly explained that Eve was created from the

23 Nurjannah Ismail, Perempuan dalam Pasungan: Bias Laki-Laki dalam Penafsiran (Yogyakarta: LKI, 2003), 64. 
rib of the Prophet Adam, which implies a lower position and status. On that basis, the principle of the Koran towards men and women is the same, where the rights of the wife are recognized equally with the rights of the husband. In other words, men have rights and obligations over women, and women also have rights and obligations over men. Therefore, the Qur'an is considered to have a revolutionary view of human relations, namely providing justice for the rights of men and women. ${ }^{24}$

Islam was born with a conception that human relations are based on justice. In addition to making decisions, women in Islam also have economic rights, namely to own their own assets, so that their husbands and fathers cannot interfere in their wealth. Ownership of such wealth includes those obtained through inheritance or from her own business. Therefore, the dowry in Islam must be paid for herself, not for her parents and cannot be taken back by her husband. ${ }^{25}$

Sayyid Qutb asserted that the excess of the share of men over women in terms of inheritance, as mentioned in the Qur'an, is due to their responsibility in life. He marries women and is responsible for the maintenance of his family, as well as for everything related to his family. That is why she is entitled

${ }_{24}$ M. Hidayat Nur Wahid, Kajian Atas Kajian Dr. Fatima Mernissi Tentang Hadis Misogini, Dalam Mansour Fakih (Ed), Membincang Feminisme Diskursu Gender Persfektif Islam (Surabaya: Risalah Gusti, n.d.), 34-35.

25 Mansour Fakih, Analisis Gender $\mathcal{E}$ Transformasi Sosial (Yogyakarta: Pustaka Pelajar, 2007). to a share equal to the share for two people; meanwhile, for women, if she has a husband, then all her needs are borne by her husband, while if she is a girl or is a widow, then her needs are met with the inheritance that she gets. Or, if not, she is borne by her male relatives. So, the differences that exist here are only differences that arise because of responsibilities, that lead to logical consequences in the distribution of inheritance. ${ }^{26}$

One of the Quranic obsessions is the realization of justice in society. Justice in the Qur'an covers all aspects of human life, both as individuals and as members of society. Therefore, the Qur'an does not tolerate all forms of oppression, whether based on group, ethnicity, skin color, ethnicity, and belief, or gender. If there is an interpretation that is oppressive or violates the noble values of humanity, then the result of that interpretation is open to reinterpretation.

Islam, which was revealed by Allah, in addition to covering things that must be absolutely believed, there are also things that can be thought about, understood, and constructed, and even have to use reason if you want to understand the meaning it contains. ${ }^{27}$

The Prophet's practice emphasizes that the message of Islam is not just a decree that must be carried out immediately, but must first be understood. Islamic messages contained

${ }^{26}$ Sayyid Quthb, Keadilan Sosial Dalam Islam, Bandung (Bandung: Penerbit Pustaka, 1984), 71.

27 Sunyoto Usman, Esai-Esai Sosiologi Perubahan Sosial (Yogyakarta: Pustaka Pelajar, 2015, 2015), 226.

e-ISSN: 2715-4580 p-ISSN: 2715-8268 
in the Qur'an and hadith have a dialogue with their audience before they can be applied. It is in this atmosphere of dialogue that understanding the inner meaning of the message is possible. In other words, the content of the message of Islam does not come like a decree without dialogue. From this assumption, Islamic scholars searched the message of Islam to formulate the main points. ${ }^{28}$

From this substantive interpretation, the view emerges that a woman may be a guardian for herself in marriage, or a mother may be a guardian for her daughter. The reason is rather casuistic. For example, when a father leaves his family and is not responsible for a long time, then he is not entitled to become a guardian, because basically the substance of the guardian is the one who is responsible. When viewed from the point of view of the closeness of a child to his parents, the mother is the one who best knows the condition of her daughter, because the mother is pregnant until she is breastfeeding even until she is an adult. However, this idea is still in the area of theoretical study that cannot be applied in society, because the current condition of society is still in the 'comfort' zone with the provisions of marriage guardians in classical figh. This idea needs to pay attention to the benefits and badness in society. If it turns out that this idea has caused a lot of controversy or confusion in the community, then there is no need to convey or socialize it first. ${ }^{29}$

Another view is that the guardian of marriage is in a father along with the next male line as a substitute if the father is not present. This provision is a religious provision that cannot be changed anymore and applies to all Muslims. However, they still consider it necessary to contextualize the understanding of gender equality, for example a mother still plays an active role in her daughter's marriage, for example, by reading a marriage sermon. This division of roles is considered as equal between a father and mother.

\section{Conclusions}

The concept of a marriage guardian when analyzed through a gender approach concludes that people who have the ability to act perfectly, both men and women, do not need a guardian, and can even become guardians for people who really need and deserve to be under their guardianship. Hadith related to the inability of women to marry themselves and become marriage guardians indicate inequalities between men and women, and strengthen the marginalization of women. In addition, the hadith about guardians of marriage is a hadith that can be interpreted based on the social setting of the hadith and the universal basic principles of Islam regarding justice.

\section{REFERENCES}

28 Zuhairi Misrawi dan Novriantoni, Doktrin Islam Progresif (Jakarta: LSIP, 2004), 56.
${ }^{29}$ Abdul Halim Abu Syuqqah, Kebebasan Wanita, 5th Ed. (Jakarta: Gema Insani, 1998), 111.

e-ISSN: 2715-4580 p-ISSN: 2715-8268 
A.Hamid Sarong. Hukum Perkawinan Islam Di Indonesia. Banda Aceh: Pena, 2010.

Abd. al-Rahman al-Jaziri. Al-Figh Ala AlMazahib Al-Arba'ah. Beirut: Dar alKutub al-Ibniyah, 2003.

Abdul Halim Mustasar Ibrahim Unes. AlMujam Al-Wasit. Mesir: Dar alMa'arif, 1973.

Abdul Majid Mahmud Mathlub. Hukum Keluarga Sakinah,. Solo: Era Intermedia, 2010.

Abdurrahman. Kompilasi Hukum Islam Indonesia. Jakarta: Akademika Pressindo, 2005.

Abu Dawud Sulaiman. Sunan Abu Dawud. Beirut: Dar al-Fikr, n.d.

Adnan Hafidh dan Ma'ruf Asroni. Tradisi Islami: Panduan Prosesi Kelahiran,Perkawinan Dan Kematian. Surabaya: Khalista, 2009.

Ahmad Azhar Basyir. Hukum Perkawinan Islam. Yogyakarta: UII Press, 1999.

Al-Asqia M. Hafidz. Kaya Wajib Bagi Orang Islam. Yogyakarta: Khazanah Sulaiman, 2011.

Al-Jabiri, M. Abid. Binyat Aql Arabi. Beirut: Markaz Dirasat al-Wihdah alArabiyyah, 2009.

al-Jamal, Sulaiman. "Hasyiyah Al-Jamal Ala Al Manhaj Li Syaikh Al-Islam Zakariyya Al- Ansharri." Beirut: Daar al-Fikr, t.t. VIII (n.d.).

Ali Engineer, Ashghar. Hak-Hak Perempaun Dalam Islam, Terjemahan Farid Wajidi. Bandung: LSPPA, 1994.

Ali, Zainuddin. Hukum Islam: Pengantar Ilmu Hukum Islam Di Indonesia. Jakarta: Sinar Grafika, 2006.

Amir Syarifuddin. Meretas Kebekuan Ijtihad Isu-Isu Penting Hukum Islam Kontemporer Di Indonesia. Jakarta:
Ciputat Press., 2005.

Anwar, Ghazala. Wacana Teologi Feminis Muslim Dalam Perspektif AgamaAgama, Geografis, Dan Teori-Teori Wacana Teologi Feminis. Yogyakarta: Pustaka Pelajar, 1997.

Arikunto, Suharsini. Manajemen Penelitian. Jakarta: Rineka Cipta, 1990.

Asmawi, Muhammad. Nikah Dalam Perbincangan Dan Perbedaan. Yogyakarta: Darrusalam, 2004.

Bahder Johan Nasution. Metode Penelitian Hukum. Bandung: Sumber Sari Indah, 2008.

Baidhawy, Zakiyuddin. Perspektif AgamaAgama, Geografis Dan Teori-Teori, Wacana Teologi Feminis. Yogyakarta: Pustaka Pelajar, 1997.

Connolly, Peter. Aneka Pendekatan Studi Agama, Terj. Imam Khairi. Yogyakarta: LkiS, 2002.

Dadang Hermawan dan Sumardjo. “Kompilasi Hukum Islam Sebagai Hukum Materil Pada Pada Peradilan Agama." Jurnal Pemikiran Hukum dan Hukum Islam 6 (2015).

Darajat, Zakiah. Islam Dan Peranan Wanita. Jakarta: Bulan Bintang, 1984.

Departemen Agama RI. Instruksi Presiden RI Nomor 1 Tahun 1991 Kompilasi Hukum Islam Di Indonesia. Jakarta: Direktorat Pembinaan Badan Peradilan Agama, 1999.

- - -. Instruksi Presiden RI Nomor 1 Tahun 1991 Kompilasi Hukum Islam Di Indonesia, n.d.

Departemen Pendidikan Nasional. Kamus Besar Bahasa Indonesia. 3rd ed. Jakarta: Balai Pustaka, 2005.

Dirjen Bimbaga Islam Depag. Ilmu Fiqih, Jilid 2. 2nd ed. Jakarta: Proyek e-ISSN: 2715-4580 p-ISSN: 2715-8268 
International Journal of Contemporary Islamic Law and Society

Vol. 3 No. 1 Tahun 2021

Pembinaan Prasarana Sarana Perguruan Tinggi Agama Islam, 1983.

Dirjen Binbaga Islam. Sejarah Penyusunan Kompilasi Hukum Islam Di Indonesia. Jakarta: Departemen Agama RI, 1991.

Djamil, Abdul. Bias Gender Dalam Pemahaman Islam. Yogyakarta: Gama Media, 2002.

Fakih, Mansour. Analisis Gender \& Transformasi Sosial. Yogyakarta: Pustaka Pelajar, 2007.

- - - Membincang Feminisme: Diskursus Gender Perspektif Islam. Surabaya: Risalah Gusti, 1996.

Fakih, Mansour dkk. Membincang Feminisme Diskursus Gender Perspektif Islam. 3rd ed. Surabaya: Risalah Gusti, 2006.

Fitria, Kholifatul. "Hak Ijbar Wali Nikah Dalam Perspektif Gender." UIN Sunan Kalijaga, 2013.

Hamdanah. Musim Kawin Di Musim Kemarau; Studi Atas Pandangan Ulama Perempuan Jember Tentang Hak-Hak. Yogyakarta: BIGRAF Publishing, 2005.

Hamidah, Tutik. Fiqih Perempuan Berwawasan Keadilan Gender. 1st ed. Malang: UIN Maliki Press, 2011.

Hasan, Mustofa. Pengantar Hukum Islam. Bandung: PUSTAKA SETIA, 2011.

Hasballah Thaib. Hukum Keluarga Dalam Syariat Islam. Medan: Universitas Dharmawangsa, 1983.

Hilary M Lips. Sex and Gender: An Introduction. California: Myfield Publishing Company, 1993.

I.P.M. Ranuhandoko B.A. Terminologi Hukum Inggris-Indonesia. Jakarta: Sinar Grafika, 2003.
Ismaill, Nurjannah. Perempuan Dalam Pasungan: Bias Laki-Laki Dalam Penafsiran. Yogyakarta: LKI, 2003. Iqbal, Muhammad, Rusli, Rusli, \& Musyahidah, Musyahidah. (2019). Management Strategies of Professional Zakat Funds for Mustahiq Family Welfare By Amil Zakat Body International Journal of Contemporary Islamic Law And Society, 1(1), 39-51.

John M. Echols dan Hassan Shadily. Kamus Inggris Indonesia. Jakarta: Gramedia, 2005.

Leonard Grob Riffat Hasan dan Hain Gordon. "Jihad Fi Sabilillah, Wornan"s Faith Journey From Struggle to Struggle", Dalam Buku Woman's and Men's Liberation. USA: Greenwood Press, 1993.

M. Hidayat Nur Wahid. Kajian Atas Kajian Dr. Fatima Mernissi Tentang Hadis Misogini, Dalam Mansour Fakih (Ed), Membincang Feminisme Diskursu Gender Persfektif Islam. Surabaya: Risalah Gusti, n.d.

Mahfud MD, Moh. Politik Hukum Di Indonesia. Jakarta: Pustaka LP3ES Indonesia, 2006.

Mahmudunasir, Syed. Islam Konsepsi Dan Sejarahnya. Bandung: PT Remaja Rosdakarya., 2011.

Maloko, Thahir. Dinamika Hukum Dalam Perkawinan. Makassar: Alauddin University Press, 2012.

Manan, Abdul. Aneka Masalah Hukum Perdata Islam Di Indonesia. Jakarta: Kencana, 2008.

Mardani. Hukum Islam. Yogyakarta: Pustaka Pelajar, 2010.

Masdar Farid Mas'udi. Islam Dan HakHak Reproduksi Perempuan: Dialog

e-ISSN: 2715-4580 p-ISSN: 2715-8268 
Fiqih Pemberdayaan. Bandung: Mizan, 1997.

Masdar Farid Mas'udi. Islam Dan HakHak Reproduksi Perempuan: Dilaog Fiqih Pemberdayaan. Bandung: Mizan, 1997.

Megawangi, Ratna. Membiarkan Berbeda: Sudut Pandang Baru Tentang Relasi Gender. 1st ed. Bandung: Mizan, 1999.

Minhaji, akhmad. Kontroversi Pembentukan Hukum Islam. Yogyakarta: UII Press, 2001.

Mohd. Idris Ramulyo. Hukum Perkawinan, Hukum Kawansan, Hukum Acara Peradilan Agama Dan Zakat Menurut Hukum Islam. 1st ed. Jakarta: Sinar Grafika, 1995.

Mudzhar, M. Atho. Membaca Gelombang Ijtihad: Antara Tardisi Dan Liberasi. Yogyakarta: Titian Ilahi Press, 1998.

Muhammad al-Syarbini. Al-Iqna'. Surabaya: Dar al-Ihya' al-Kutub alArabiyyah, 2003.

Muhammad Ali As-Shabuni. Rawailul Bayan Tafsir Ayat Al-Ahkam Min AlQur'an,. 2nd ed. Jakarta: Dinamika Berkat Utama, n.d.

Muhammad, Husein. Islam Agama Ramah Perempuan Pembelaan Kiai Pesantren. Yogyakarta: LkiS, 2004.

Mulia, Siti Musdah. Keadilan Kesetaraan Gender Perspektif Islam. 2nd ed. Jakarta: LKAJ, 2003.

Nasution, Khoiruddin. Hukum Perkawinan I Dilengkapi UU Negara Muslim Kontemporer. Yogyakarta: Academia Tazzafa, n.d.

Nata, Abuddin. Metodologi Studi Islam. Jakarta: PT. Grafindo Persada, 2006.

Nurdin, Nurdin, \& Yusuf, Khaeruddin. (2020). Knowledge management lifecycle in Islamic bank: the case of syariah banks in Indonesia. International Journal of Knowledge Management Studies, 11(1), 59-80. doi: 10.1504/ijkms.2020.105073

Pustaka Widyatama. Kompilasi Hukum Islam. 1st ed. Yogyakarta, 2004.

Qasim Amin. The New Women: A Document in the Early Debate of Egyptian Feminism", Diterjemahkan Syariful Alam, Sejarah Penindasan Perempuan. Yogyakarta: IRCiSod, 2003.

Rahim Afandi Abdul dan Mohd Anwar Ramli. Pemikiran Teologi Islam Di Malaysia. Malaysia: UPSI, 2013.

Rasji, Sulaiman. Figh Islam. Jakarta: Attahiriyah, 2001.

Rusli Rusli, Islamic Feminism: Responses of Muslim Feminists to Gender Inequality in Indonesia (Palu: Irshed Press, 2006).

Rusli Rusli, "An Analysis of Islamic Feminism in Indonesia: Reconstruction of Islamic Legal Issues on Gender Relations," Hunafa: Jurnal Studia Islamika 3, no. 1 (2006): $1-12$,

https://www.jurnalhunafa.org/ind ex.php/hunafa/article/view/239

Rusli. "Isu-Isu Gender Dalam BingkaiI Metodologi Studi Islam." Musawa Vol. 4 (2012).

Rusli Rusli, "Hermeneutical Reading of Țalāq," HUNAFA: Jurnal Studia Islamika 12, no. 2 (2016): 209-229.

Rusyd, Ibnu. Bidayatul Mujtahid, Jilid II, Terjemahan Imam Ghazali Said $\mathcal{E}$ Ahmad Zaidun. Jakarta: Pustaka Amani, 2007.

- - . Bidayatul Mujtahid. 3rd ed. Jakarta: Pustaka Azzam, 2007.

e-ISSN: $2715-4580$ p-ISSN: 2715-8268 
International Journal of Contemporary Islamic Law and Society

Vol. 3 No. 1 Tahun 2021

Sabiq, Sayyid. Fikih Sunnah (Alih Bahasa Oleh Moh. Thalib). Bandung: Al Ma"earif, 1997.

- - - Fighu Al-Sunnah, (Beirut: Dar AlFikr, Tt.), II: Hlm. 5). 2nd ed. Beirut: Dar Al- Fikr, tt.), II:, n.d.

Sabri Sarmin dan Andi Nurmaya Aroeng. Fikih II. Makassar: Alauddin University Press, 2010.

Saleh, Qamarudin. Asbabun Nuzul. Bandung: CV. Diponegoro, 1948.

Sayyid Quthb. Keadilan Sosial Dalam Islam, Bandung. Bandung: Penerbit Pustaka, 1984.

Sikti, Ahmad. Daf'u Al-Darar Dalam Putusan Hakim Pengadilan Agama. Jakarta: A- empat, 2015.

Siti Ruhaini Dzuhayatin. "Pergulatan Pemikiran Feminis Dalam Wacana Islam Di Indonesia", Dalam, Siti Ruhaini Dzuhayatin, Dkk., Rekonstruksi Metodologis Wacana Kesetaraan Gender Dalam Islam. Yogyakarta: PSW UIN Sunan Kalijaga, 2002.

Soekanto, Soekarno. Pokok-Pokok Sosiologi Hukum Islam. Jakarta: Rajawali Press, 1988.

Soemiyati. Hukum Perkawinan Islam Dan Undang-Undang Perkawinan (UndangUndang No. 1 Tahun 1974 Tentang Perkawinan). Yogyakarta: Liberty, 2007.

Somad, Abd. Hukum Islam. Jakarta: Kencana, 2010.

Somawinata, Yusuf. "Al-Maslahah AlMursalah Dan Implikasi Terhadap Dinamisasi Hukum Islam Di Indonesia." Hukum Sosial dan Keagamaan 4 No. 2 (2010).

Sukaenah, Sukaenah, Rusli, Rusli, \& B, M. Taufan. (2020). The
Effectiveness of Indonesia Supreme Court Regulation Number 1 Year 2016 Concerning Mediation of Marriage Disputes International Journal Of Contemporary Islamic Law And Society, 2(1), 63-80.

Susanto, Edi. Dimensi Studi Islam Kontemporer. Jakarta: Prenadamedia Group, 2018.

Syafiq. Bebas Dari Patriarkhisme Islam. Depok: KataKita, 2010.

Syarifuddin, Amir. Garis-Garis Besar Figh. Jakarta: Kencana Prenada Media Group, 2010.

- - - Hukum Perkawinan Islam Di Indonesia: Antara Figh Munakahat Dan Undang-Undang Perkawinan. 3rd ed. Jakarta: Kencana Prenada Media Group, 2009.

Syuqqah, Abdul Halim Abu. Kebebasan Wanita, 5th Ed. Jakarta: Gema Insani, 1998.

Taimiyah, Ibnu. Hukum-Hukum Perkawinan, Alih Bahasa Oleh Rusnan Yahya. Jakarta: Pustaka al-Kausar, 1997.

Tihami. Kajian Figh Nikah Lengkap. Jakarta: PT. Raja Grafindo Persada, 2009.

Tim Penyusun Kamus. Kamus Besar Bahasa Indonesia. Jakarta: Balai Pustaka, 2002.

Toshihiko Izutsu. "Ethico-Religious Consepts in the Quran", Diterjemahkan Agus Fakhri Husain, Konsep-Konsep Etika Religius Dalam Al-Quran. Yogyakarta: Tiara Wacana, 2003.

Umar, Nasaruddin. Argumen Kesetaraan Jender: Perspektif Al-Qur'an. Cet. I. Jakarta, 1999.

Umar, Nasarudin. Narasudin Umar, e-ISSN: 2715-4580 p-ISSN: 2715-8268 
International Journal of Contemporary Islamic Law and Society

Vol. 3 No. 1 Tahun 2021

Argumen Kesetaraan Gender Dalam

Perspektif Alqur'an, (Jakarta:

Paramadina. 1999), Hal.75. Jakarta:

Paramadina, 1999.

Usman, Sunyoto. Sunyoto Usman, Esai-

Esai Sosiologi Perubahan Sosial.

Yogyakarta: Pustaka Pelajar, 2015, 2015.

Waryono Abdul G. dan Muh. Isnanto. Isu-Isu Gender Dalam Kurikulum Pendidikan Dasar Dan Menengah. Yogyakarta: PSW UIN SUKA dan IISEP, 2004.

Yunus, Haerunnisa, Rusli, Rusli, \& Abidin, Abidin. (2020). The Concept of A Marriage Agreement in the Compilation of Islamic Law International Journal Of Contemporary Islamic Law And Society, 2(2), 35-45.

Zuhairi Misrawi dan Novriantoni. Doktrin Islam Progresif. Jakarta: LSIP, 2004.

"(Jurn Al Studi Dan Penelitian Hukum Islam), Tali Tulab." Jurnal Ulul Albab Vol.1, No., no. Tinjauan Status Wali Dalam Perkawinan berdasar Pendekatan Feminis (2017).

Ensiklopedi Hukum Islam,. 6th ed. Jakarta:

PT. Ichtiar Baru van Hoeve, n.d. 